\title{
Nits of Louse on the hairs of Holy Maria-Magdalena: a SEM-EDX study
}

\author{
Gérard Lucotte $^{1 *}$, Areki Izri ${ }^{2}$ and Thierry Thomasset ${ }^{3}$ \\ ${ }^{1}$ Institute of Molecular Anthropology, Paris, France \\ ${ }^{2}$ Laboratory of Parasitology and Mycology, Bobigny, France \\ ${ }^{3}$ Laboratory of Physico-Chemical Analyses, UST of Compiègne, France
}

\begin{abstract}
Background: Presence of nits of louse on the hairs of potential Holy Maria-Magdalena.

Objective: Electron microscopic studies of the hairs, to find nits on the hair surfaces.

Methods: SEM-EDX studies of ten conserved hairs.
\end{abstract}

Results: The results show five microscopic features characteristic of nits, each spreading out on different hairs; embryos can be distinguished in four eggs on five. These results indicate that Maria-Magdalena's hairs had been massively infested by nits of louse.

\section{Introduction}

Holy Maria-Magdalena (3?-63?) is the most abundantly cited women of the four Gospels. According to the French "Tradition des Saints de Provence" [1], she (and her companions) landed to the present French Mediterranean shores (in a region corresponding to the current part of Les-Saintes-Maries-de-la-mer) and attained further the towns of Marseilles and Aix-en-Provence. Thereafter, she withdrew for thirty years to the cave of La-Sainte-Baume, where she died. She was buried in the currently named village of Saint-Maximin-la-SainteBaume.

Some relics (cranium, bones and hairs) of the presumed MariaMagdalena were kept in the Saint-Maximin basilica, where a large lock of Maria-Magdalena's hairs is arranged in a dedicated reliquary. We have obtained some hairs from this lock, for scientific purpose (microscopic examinations and chemical analysis). We have published these last years our observations of fennel rests [2], marine microremains [3], silver and gold particles [4], skin debris [5] and mineral particles [6] deposited on the hair surfaces.

We report here our observations and analyses of nits (of lice) adhering to some of the hairs studied.

\section{Material and methods}

The material is ten hairs, numbered 1 to 10 , from the lock of MariaMagdalena's hairs [7]. They were placed on a sterile adhesive paper, for SEM (Scanning Electron Microscopy) observations and EDX (Energy Dispersive X-Ray spectroscopy) analyses.

The SEM apparatus used is the FEI model Quanta FEG (an environmental electron microscope). Elemental analyses of the structures observed on this apparatus were carried out because it is equipped with the probe model X-flash 6/30. Both LFD (Large Field Detector) and CBS (Circular Back Scattering) procedures were used, the last one to better detect heavy elements. Each elemental analysis is given in the form of a spectrum, with kiloelectrons / Volts (ke/V) on the abscissa and elemental peak heights $(\mathrm{cps} / \mathrm{eV})$ in ordinates.

Figure 1 gives a schematic representation [8] of a nit of lice (Pediculus humanus capitis). It is an egg-shaped structure, of about 50$100 \mu \mathrm{m}$ of length, adhering by its basis to the hair surface. The lower edge of the structure is the pedicel; operculum is the opening cover located on the other side of the nit. When the egg is full, an embryo is clearly visible inside the external outline of the nit.

\section{Results}

Structures similar to nits (oversimplified in Figure 1) are detected on hair numbers $3,4,7,9$ and 10 .

\section{A first nit on hair number 3}

Figure 2 shows the nit found on some part of hair number 3: an egg-shaped structure of about $50 \mu \mathrm{m}$, adhering to the hair surface. It is apparently intact, with a pedicel, a bulging body containing an embryo, and a closed operculum. The operculum opening is oriented along the scale points of the hair.

At least four calcite $\left(\mathrm{CO}_{3} \mathrm{Ca}_{2}\right)$ particles are deposited on the egg body. EDX analysis establishes that the nit is rich in organic matter (carbon, oxygen and nitrogen of the chitin), the same elements plus sulphur (of the keratin), and with calcium and aluminosilicate deposits.

*Correspondence to: Pr Gérard Lucotte, Institute of Molecular Anthropology, 42, Monge Street, 75005 Paris, France, Tel: 06835659 80; E-mail: lucotte@hotmail.com

Key words: Maria-Magdalena's hairs, nits of louse, SEM-EDX studies

Received: September 01, 2020; Accepted: September 14, 2020; Published: September 18, 2020 


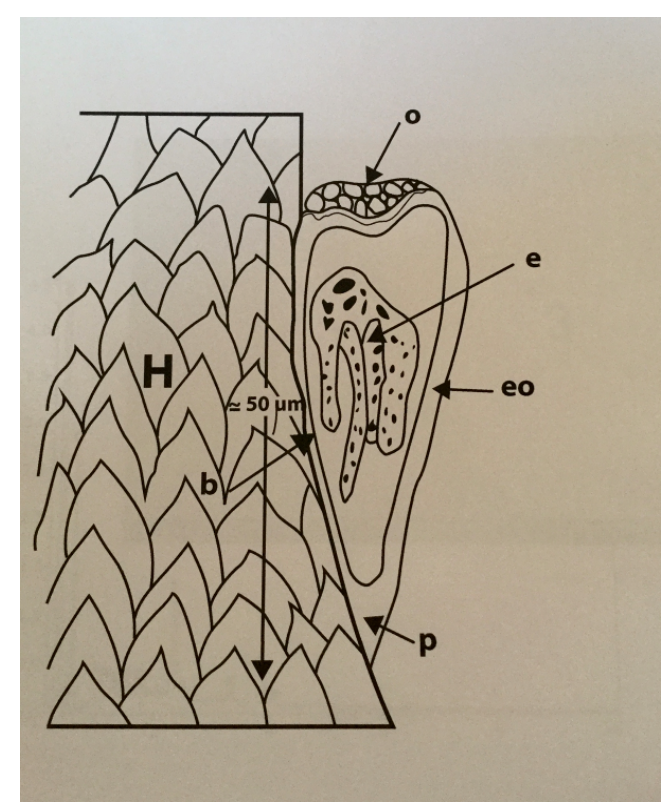

Figure 1. Shematic representation of a nit, adhering on a hair $(\mathrm{H})$ surface $(\mathrm{O}$ : operculum; $\mathrm{p}$ : pedicel; e: embryo; b: basis of the nit on the hair; eo: external outline of the nit)

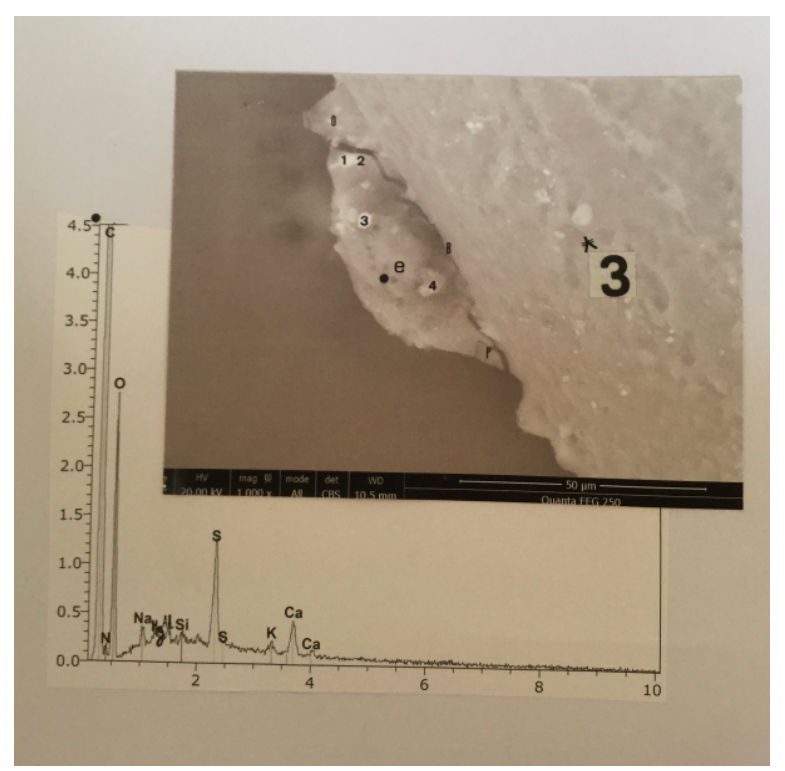

Figure 2. A nit on hair number 3. Above: SEM photograph (in CBS, 1000x) of the nit Arrow point above 3 indicates hair scale point orientations (o: operculum; p: pedicel; e: embryo; B: basis); 1, 2, 3 and 4 are calcite particles. The black point indicates the location where EDX analysis is realized. Below: spectrum at the black point. C: carbon; N: nitrogen; $\mathrm{O}$ : oxygen; Na: sodium; $\mathrm{Mg}$ : magnesium; Al: aluminium; Si: silicium; $\mathrm{S}$ (two peaks): sulphur; K: potassium; Ca (two peaks): calcium.

\section{A second nit on hair number 4}

Figure 3 shows the nit observed on hair number 4 . It is apparently an empty egg, with a flattened surface and without operculum. The structure is conserved because the presence of a salt $(\mathrm{NaCl})$ mineral particle located on the egg body; salt mineral particles were already found on the hair surfaces [3].

As for the other nits observed, the operculum aperture is oriented along the scale points of the hair, towards the end extremity of the hair.

EDX analysis of the nit shows that it is constituted of the same elements, plus salt, that the previous nit.

\section{A third nit on hair number 7}

Figure 4 shows a bulging nit adhering to the hair number 7 surface. It is apparently an intact egg, with a closed operculum and an embryo observed inside. The nit composition is identical to that of the first egg previously analysed.

\section{A fourth nit on hair number 9}

Figure 5 shows a nit almost completely detached from the surface of the hair number 9 (it was already pointed out in 5). An embryo is clearly visible inside of the nit body. The nit composition is also identical to those of the other eggs already analysed.

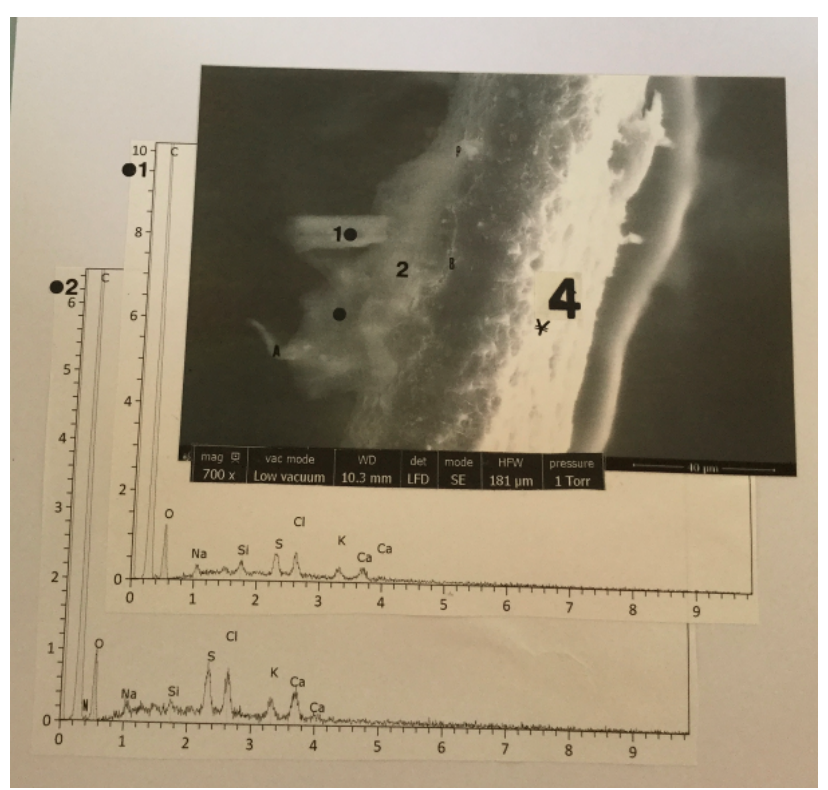

Figure 3. A nit on hair number 4. Above: SEM photograph in (LFD, 700x) of the nit (2: the nit; B: basis; A: residue of the operculum; 1: the salt particle). Below: spectras of $\mathbf{1}$ (above) and 2 (below). C: carbon; N: nitrogen; O: oxygen; Na: sodium; Si: silicium; Cl: chlorine; $\mathrm{K}$ : potassium; $\mathrm{Ca}$ (two peaks): calcium

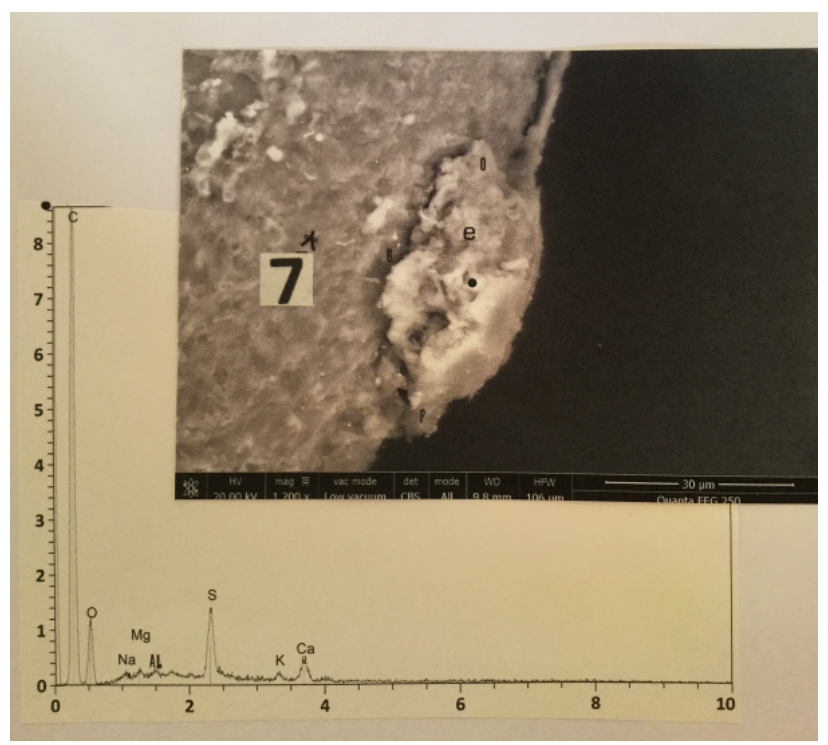

Figure 4. A nit on hair number 7. Above: SEM photograph (in CBS, 1200x) of the nit (o operculum; p: pedicel; b: basis; e: embryo). Below: spectrum at the black point. C: carbon; $\mathrm{O}$ : oxygen; $\mathrm{Na}$ (traces): sodium; Mg: magnesium; Al (traces): aluminium; S: sulphur; K: potassium; Ca (two peaks): calcium 


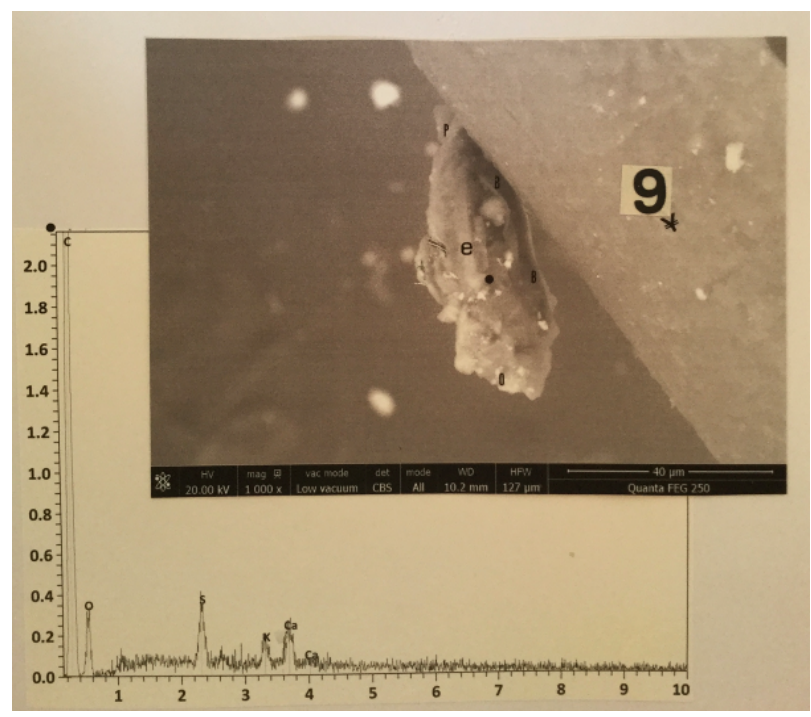

Figure 5. A nit on hair number 9. Above: SEM photograph (in CBS, 1000x) of the nit (o: operculum; p: pedicel; b: basis; e: embryo). Below: spectrum at the black point. C: carbon; O: oxygen; S: sulphur; K: potassium; Ca (two peaks): calcium

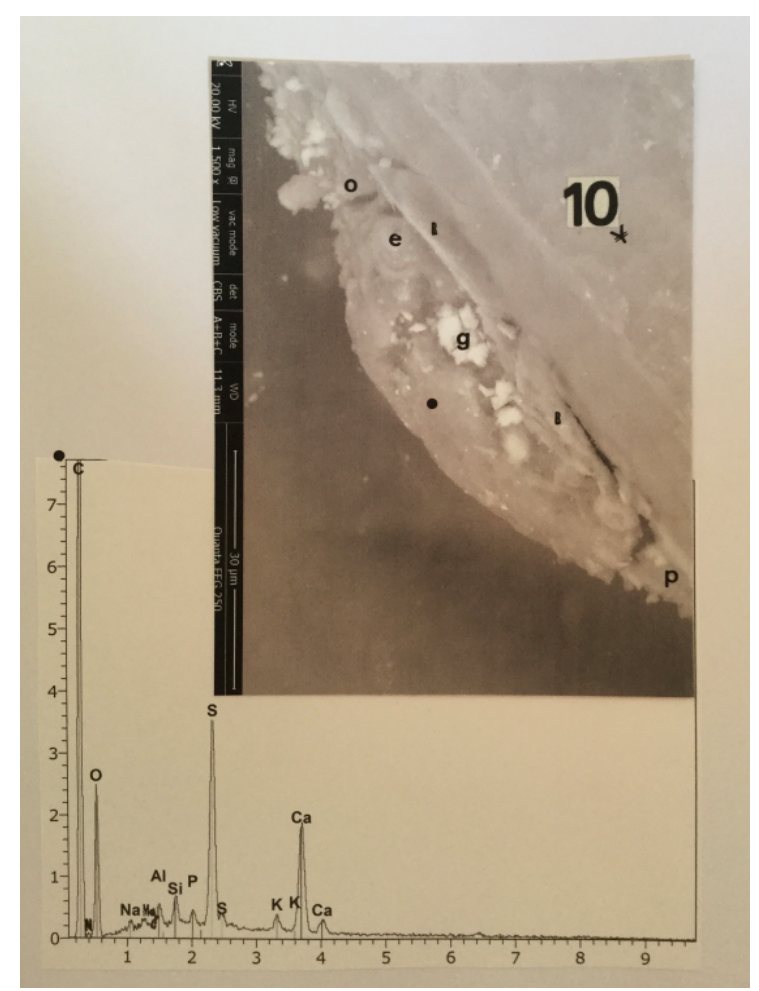

Figure 6. A nit on the hair number 10. Above: SEM photograph (in CBS, 1500x) of the nit (o: operculum; p: pedicel; B: basis; e: embryo; g: gypsum particles). Below: spectrum at the black point. C: carbon; N: nitrogen; O: oxygen; Na: sodium; Mg: magnesium; $\mathrm{Al}$ : aluminium: Si: silicum; P: phosphorous; $\mathrm{S}$ (two peaks): sulphur; K (two peaks): potassium; $\mathrm{Ca}$ (two peaks): calcium

\section{A fifth nit on hair number 10}

Figure 6 shows a nit adhering to the hair number 10 surface. The structure of this nit is completely conserved, with a closed operculum and a blown-up body containing an embryo.

Several particles of gypsum $\left(\mathrm{CaSO}_{4} \cdot 2 \mathrm{H}_{2} \mathrm{O}\right)$ are deposited on the nit body; gypsum mineral particles were also already found on the hair surfaces [3]; together with salt, they indicate a marine environment.
The nit composition is like those already analysed, plus phosphorous (that of calcium phosphate); that indicates some internal calcification of this peculiar nit.

\section{Discussion}

Table 1 summarizes one of the main characteristics of the nits we have detected: Nits are found on one half (5 out of 10) of the hairs studied; when present, only one nit is found per hair; all the nits observed, but the second one, are full and there are visible embryos inside.

All the nits observed, but the fourth one, are egg-shaped structures that adhere to the hair surfaces along a distance of about $50 \mu \mathrm{m}$ of length. Their upper orifices are opened, as the rule [9], towards the end

Table 1. Listing of the nit characteristics, located on the hairs

\begin{tabular}{|c|c|c|c|}
\hline Hair numbers & $\begin{array}{c}\text { Nit presence (+)/ } \\
\text { absence (-) }\end{array}$ & Nit numbers & $\begin{array}{c}\text { Visible embryos in } \\
\text { the nits }\end{array}$ \\
\hline $\mathbf{1}$ & - & & \\
\hline $\mathbf{2}$ & - & & + \\
\hline $\mathbf{3}$ & + & 1 & \\
\hline $\mathbf{4}$ & + & 1 & \\
\hline $\mathbf{5}$ & - & & + \\
\hline $\mathbf{6}$ & - & & \\
\hline $\mathbf{7}$ & + & 1 & + \\
\hline $\mathbf{8}$ & - & & + \\
\hline $\mathbf{9}$ & + & 1 & + \\
\hline $\mathbf{1 0}$ & + & 1 & + \\
\hline
\end{tabular}

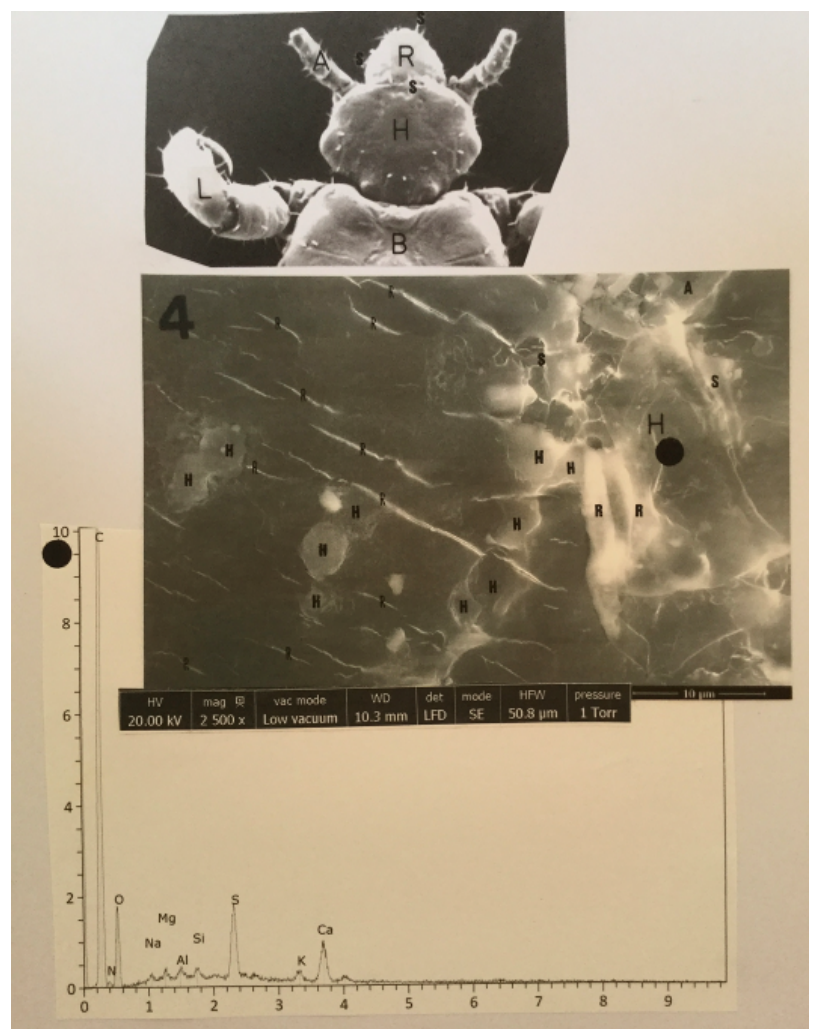

Figure 7. A possible loose head on the surface of the hair number 4. Upper photograph: SEM photograph of a loose head. H: head; R: rostrum; B: body; A: left antennae; L: left leg; S: silks. Lower photograph: SEM photograph (in LFD, 2500x) of a possible loose head on the hair surface. H: head; A: antennae basis; S: silks; R: two parts of a rostrum; H: red cells; R: limits of scale rows on the hair. Below: spectrum at the black point (the head): C: carbon; N: nitrogen; O: oxygen; Na: sodium; Mg: magnesium; Al: aluminium; Si: silicium; $\mathrm{K}$ : potassium; $\mathrm{Ca}$ (two peaks): calcium 
extremities of hairs. Their chemical compositions are conforming to its chitinized, sclerified and calcified natures.

Typically, there is only one nit per infested hair [9]. That we don't observe nits on the five other hairs studied could be due to the fact that the hairs under study are cut hairs [7]: they are only hair portions and nits could be observed on other parts (not studied) of the nonbearing nit hairs; another possibility is that nits were detached from hairs during the hair conservation process. If one nit was present on each hair, that corresponds to a maximal infestation by loose of the head bearing these hairs.

All the nits observed, but the second one, correspond to nonhatched eggs. That seems to indicate that the individual bearing these hairs died suddenly (this rapid death interrupted the hatching process of the eggs). The relatively little size of the nits detected is in favour of eggs at the early time of their development.

Do we have some evidence of loose individuals, or parts of its, conserved on the surface of the hairs studied? One unique of that is represented on Figure 7, which shows possible rests of a stinging insect conserved on some part of the hair number 4 surface: we can distinguish a relatively voluminous organic and calcified head (with at least two silks, emergence of a part of an articulated antennae from the head extremity, and perhaps some parts of a rostrum apparatus), the whole bathing in a pool of at least ten possible (after size, form and aspect) human red cells. But with this sort of observation, we cannot establish if that corresponds to the rests of louse, of flea, or of buy (only flea and buy had a specific apparatus to stuck the blood).

That Maria-Magdalena had louse is not very surprising because of the oldness of the character for lice is a very ancient companion of man, since the time of human clothing [10]. Herodote indicates that the Egyptian priests protected themselves against vermin infections by shaving entirely the cranium, and also eyebrows and eyelashes.

The most widely quoted early reference to lice is written in Exodus 8: 17, which records that Aaron "stretched out his rod and smoke the dust of the earth, and it became lice in men and beast." The first published paleoparasitologic study on Egyptian mummies reported that they were covered by lice and eggs [11]. Egg structures compatible with those of nits, studied in SEM-EDX, were found [12] on hairs in the ashes of Herculaneum, Italy. Body loose leg extremities were also observed in ancient textiles excaved at Massada, Israel [13].

Christian hermits considered lousiness as a sign of humility and a saintly way of life. The Moslem tradition prohibits killing of lice in mosques and in other holy places, whereas the Jewish tradition -Maria-Magdalena was Jewish by her mother [7] - forbids killing of lice on the Sabbath.

\section{Conclusion}

In conclusion, our study shows that we have detected five nits on the surface of the ten hairs of Maria-Magdalena studied.

Observed in SEM, the nits found show all the characteristics (morphology, length, setting up...) of adhering eggs on the hair surface [8]. Their opened apertures are oriented towards hair terminal extremities. EDX analyses show that they are constituted mainly by organic matter, with some sorts of keratinisation and calcification.

According to the general rule [9], only one nit is detected on the surface of the hairs (numbers 3, 4, 5, 7 and 10) bearing its. But we don't exclude, because hairs studied are cut hairs, that nits are also present on the five other hairs; another explanation is that nits have been detached since many times during the long term conservative process of hairs. If it was the case, i.e. one nit per hair in fact, the hairs we studied were maximally infested by loose nits.

All the five nits detected, but one, contained embryos inside. Together with their relatively little sizes, this indicates that eggs were killed suddenly and massively at an early step of their developments.

Given the great oldness of Maria-Magdalena's remains, at one period where hygiene habits were not so drastic as today, it is not so surprising that the hairs of Holy Maria-Magdalena would be massively infested by snits of loose. An apparent paradox is that, according to historical data [14], Maria-Magdalena was a very rich person who could have many facilities to buy and obtain protective capillary products; but, according to the French "Tradition des Saints de Provence" [15], she withdrew as an hermit for the last thirty years of her life to the cave of La-Sainte-Baume, where she died.

\section{Acknowledgements}

We thank Florian Racine, the priest of the Saint-Maximin-laSainte-Baume basilica, who furnished to us the Maria-Magdalena's hairs and for his initial financial help to the study.

\section{References}

1. Trouillet MC (2016) The relics of Holy Maria-Magdalena (in French). Petrus Ed., Aixen-Provence.

2. Lucotte G, Thomasset T, Salmon A (2018) Fennel (Foeniculum vulgare) rests on the holy Maria-Magdalena's hairs, studied by scanning electron microscopy and elemental analysis. Archeo Discov 6: 216-270.

3. Lucotte G, D'Hérissart E, Thomasset T (2019) Marine micro-remains on holy MariaMagdalena's hair, studied by scanning electron microscopy and elemental analysis. Archeol Discov 7: 155-191.

4. Lucotte G (2019) Silver and gold on the hairs of holy Maria-Magdalena, studied by scanning electron microscopy and elemental analysis. Archeol Discov 7: 257-282.

5. Lucotte G, Thomasset T, Borensztajn S (2020) Skin debris on the hairs of holy MariaMagdalena: a SEM-EDX analysis. Int J Sciences 9: 57-79.

6. Lucotte G (2020) Mineral particles found on the hairs of holy Maria-Magdalena studied by scanning electron microscopy and elemental analysis. Open J Appl Sciences 10: 41-59.

7. Lucotte G (2016) The mitochondrial DNA mitotype of Sainte-Marie-Madeleine. Int J Sciences 5: 10-19.

8. Alba-Tercedor J, Sanchez Almazo I (2014) The use of micro-CT for the study of eggs and development in insects: a comparison of two microtomographs. Microsc and Anal 28: 7-10

9. Buxton PA (1946) The Louse. Williams and Wilkins Ed., Baltimore.

10. Kittler R, Kayser M, Stoneking M (2003) Molecular evolution of Pediculus humanus and the origin of clothing. Curr Biol 13: 1414-1417.

11. Ruffer MA (1921) Studies on paleopathology of Egypt. Chicago University Press.

12. Capasso L, Di Tota G (1998) Lice buried under the ashes of Herculaneum. The Lancet 351: 992 .

13. Mumcuoglu KY, Zias J, Tarshis M, Lavi M, Stiebel GD (2003) Body louse remains found in textiles excaved at Massada, Israel. J Med Entomol 40: 585-587.

14. De Voragine J (2014) The Golden Legend (in French). Poche Ed., Paris.

15. Franzoni A (2016) Holy Maria-Magdalena and the Saints of Provence in the French tradition of Saints of Provence, vol. 3 (in French). ASTSP Ed., Plan d'Aups Sainte-Baume.

Copyright: (C2020 Lucotte G. This is an open-access article distributed under the terms of the Creative Commons Attribution License, which permits unrestricted use, distribution, and reproduction in any medium, provided the original author and source are credited. 